\title{
DEVELOPMENT MONOPOLY MEDIA TO INCREASE STUDENT'S MOTIVATION STUDY OF SOCIAL SCIENCES IN MIDDLE SCHOOL
}

\author{
Ichmi Yani Arinda Rohmah, \\ Department of Sociology, \\ Faculty of Social and Political Sciences Universitas Nasional, Indonesia \\ Email: ichmi@civitas.unas.ac.id
}

\begin{abstract}
Research and development of Monopoly media are carried out using Borg and Gall product development procedures. The development of Monopoly learning media is carried out to increase student learning motivation on social sciences material in the second semester of class VII at SMP Muhammadiyah 9 Surabaya. Media development is carried out through two validity tests. The results of the feasibility test show different values. The final results show that the developed learning media get $80 \%$ good and $90 \%$ outstanding, so in this case, the Monopoly learning media in Social Sciences studies is suitable for student learning. Based on observations made by researchers shows that after the application of Monopoly learning media, students have better motivation and focus than before applying Monopoly media.
\end{abstract}

Keywords: monopoly media, motivation, students.

\section{Introduction}

Education, as the basic needs of the nation's generation that must be met, the development of an increasingly advanced era has a considerable influence on today's young generation's world of education. Starting from the influence of the learning environment that begins to change from before, affecting students' motivation and learning styles. It makes learning activities in schools need to be considered, especially by teachers in the field of study. The learning process will also have a strong influence on understanding students' knowledge and behavior.

Often learning activities are understood as activities that influence a person to understand and respond to and act individually and in groups. Learning can be done anywhere, anytime, and in various forms, both psychomotor, affective, and cognitive. Learning activities are also not limited to space and time (Miftahul Huda: 2014).

Learning activities that have been planned by the teacher in the field of study can increase motivation and provide good results for students. It requires a teacher to creatively design learning activities for students, not just passive acceptance of knowledge. Teachers must design learning activities that can respond emotionally, sociologically, psychologically, and 
physiologically to students (Miftahul Huda: 2014).

Based on the problems encountered by researchers in learning in class, students when they find the change in the third hour, and so on, students tend to decrease motivation to learn in Social Sciences (IPS) subjects. However, students need to learn and understand many materials to increase their level of knowledge. The level of learning motivation in students also influences the value of learning outcomes in Social Sciences studies. As social studies subject teachers, researchers understand the characteristics of many IPS study materials in the form of explanations. Also, it is in the form of descriptive sentences presented in the field of study books, so students need to get a new learning media design to increase learning motivation and learning outcomes at the same time.

Learning motivation is essential to be maintained in every student because it needs to be known that there are three functions of motivation in a person. Namely, motivation can be a driving force in a person. Motivation gives direction to one's actions to achieve the desired goals. Motivation can encourage someone to sort out the actions that must be done (Sardiman A.M.: 2007).

Designing media with new concepts and developing them creatively according to Core Competencies (KI) and Basic Competencies $(\mathrm{KD})$ is necessary, especially in learning at the research object location. It is because the learning process can also affect students in achieving the objectives of the learners (Oemar Hamalik: 1992).

Research and development of instructional media by researchers is fascinating to do. Based on the background of the research problem, the formulation of the problems in this study is: (1) How to develop media of Monopoly media in Social Sciences (IPS) subjects and (2) How to motivate student learning after using Monopoly media in eyes Class VII Social Sciences lessons at Muhammadiyah 9 Surabaya Middle School. The research object conducted by researchers is the students of class VII semester 2 of SMP Muhammadiyah 9 Surabaya. The study was conducted in April 2017.

\section{Research Method}

The research method used by researchers is Research and Development (R\&D). R\&D research methods are research methods used to produce products through the validity and effectiveness of the product being developed (Sugiyono:2013).

This type of Research and Development conducted by researchers uses the Borg and Gall product research and development procedure. According to Bord and Gall, there are ten stages in product research and development, namely the first research and information collecting. In this first stage, researchers conducted several activities, including the study of literature relating to the research issues raised, researchers 
measuring needs, and research conducted on a small scale. Also, researchers prepare to formulate a framework that will be carried out in the next research phase (Tatik Sutari dan Edi Irawan: 2017).

In the second stage of planning, the researcher compiles a research plan by formulating the research problem and the research objectives to be achieved. Third, develop a preliminary form of products. Researchers design the initial form of the product being developed; the researcher also prepares guidelines or references as instructions for evaluating the feasibility of the product being developed. Fourth preliminary field testing, researchers conduct initial field trials involving 6 to 12 subjects. In this step, the researcher can collect data by interview and observation (Tatik Sutari dan Edi Irawan: 2017).

In the fifth stage of playing the product revision, researchers made improvements to the product developed based on the initial trials' results. The sixth is playing field testing; the researcher conducts product trials for the second time with many product user subjects. Seventh operational product revision, researchers made improvements to the products that have been tested. Eighth operational field testing, researchers validate the products produced using questionnaires, interviews, and observations then proceed with the analysis of validation results. Ninth final product revision, researchers make final improvements to the product being developed.
Tenth, dissemination, and implementation, researchers conducted disseminating products developed to the public, especially in the academic arena (Tatik Sutari dan Edi Irawan: 2017).

Researchers use interview techniques, observation, written tests, and documentation for data collection techniques for learning outcomes and changes in student motivation. Interview (interview) the researcher conducted a dialogue with the informant. Participant observations are observations made by researchers and researchers involved in the object observation activities. Documentation, the researcher collects documents containing information relating to research data (Ambo Upe:2010). A test is a tool used to measure the object's ability under study (Suharsimi Arikunto: hl.223).

The first is open and structured interviews; researchers conduct interviews with predetermined informants, namely students and experts who validate the researchers' products. Second, participant observation, the researcher made observations to students before and after implementing the Monopoly of media learning, observations were carried out in the study of Social Sciences (IPS). The third test technique is that the researcher conducts two tests (pretest and post-test). The four documentation techniques are carried out by collecting documents relating to students' learning process and in the form of photos of learning activities in the classroom. 
This study's data analysis techniques were divided into four categories: learning content analysis, data analysis of the feasibility of product validity results, analysis of learning outcomes, and learning motivation.

Researchers do the first, learning content analysis by adjusting learning media based on Core Competencies (KI), Basic Competencies (KD), and indicators. Here KI and $\mathrm{KD}$ are used as a basis for developing learning media:

(KI-1) Appreciate and live the teachings of the religion they hold. (KI-2) Respect and appreciate honest behavior, discipline, responsibility, care (tolerance, cooperation), polite, confident in interacting effectively with the social and natural environment within reach of relationships and existence. (KI-3) U n d e r s t a n d i n g knowledge (factual, conceptual, and procedural) based on curiosity about science, technology, art, culture related to phenomena and events seen in the eye. (KI-4) Trying, processing, and presenting in the realm of concrete (using, decomposing, assembling, modifying, and making) and abstract domains (writing, reading, calculating, drawing, and composing) following what is learned in school and other sources in the same perspective/theory. (KD 4.3) Presents the results of an analysis of human interactions with the natural, social, cultural, and political environment that results in various economic activities.

Indicators: Students can understand and explain various kinds of economic activities in daily life and community efforts in meeting the needs of life.

Second, the product feasibility test analysis is done descriptively based on the developed product assessment questionnaire. The eligibility criteria for the product use the following percentage:

Table 1 Product Eligibility Criteria

\begin{tabular}{cl}
\hline Percentage (\%) & \multicolumn{1}{c}{ Product Eligibility Criteria } \\
\hline $90-100$ & Very good, no revision needed \\
$80-89$ & Good, there is no need for revision \\
$70-79$ & Good enough, no revision needed \\
$60-69$ & Not good; needs revision \\
$<60$ & Not very good. All need to be revised \\
\hline
\end{tabular}

Analysis of learning motivation using Miles and Huberman analysis techniques consists of four stages: data collection, data reduction, data display and verification, and conclusion drawing (Sugiyono:2013).

\section{Development of Monopoly Media in Social Sciences Learning}

Monopoly media in the field of Social Sciences study is one type of board game that can be used for teaching and learning 
activities in schools. The teacher can independently design the Monopoly under the Social Science (IPS) study material that supports it attractively to increase students' learning motivation.

The development of a monopoly type of learning media for social science is straightforward to be developed independently by the teacher. The capital costs used for media development tend to be cheap and the materials used are relatively easy to obtain. Besides, the concept of monopoly games has long been known by school-age children, so they are no strangers to the use of instructional media that have concepts almost similar to monopoly games in general,

Monopoly learning media is very relevant to be used as a learning medium on material about community activities in meeting the needs of life, namely in the second semester of Social Sciences studies class VII junior high school. In Monopoly, the concept and all its media designs are adjusted to the needs to explain the material taught. Also, the design of the images used in the Monopoly media is adapted to students' lives in meeting the needs of life.

The aim of developing Monopoly learning media is following the learning indicators that are to be achieved. Namely, students can understand and explain various kinds of economic activities in daily life and community efforts in meeting the needs of life. The target of using Monopoly media is students of class VII junior high school in Social Sciences (IPS) semester 2 (two).

Monopoly Learning Media Components (tools and materials used) covers a monopoly media to consist of 24 objects or places to meet students' needs. Also, there are four places to take opportunity cards and two places to collect scholarship fund cards, pieces that represent pemaian, two dice, monopoly money, scholarship fund card, chance card. The development of Monopoly's learning media on Social Sciences (IPS) studies uses two feasibility tests.

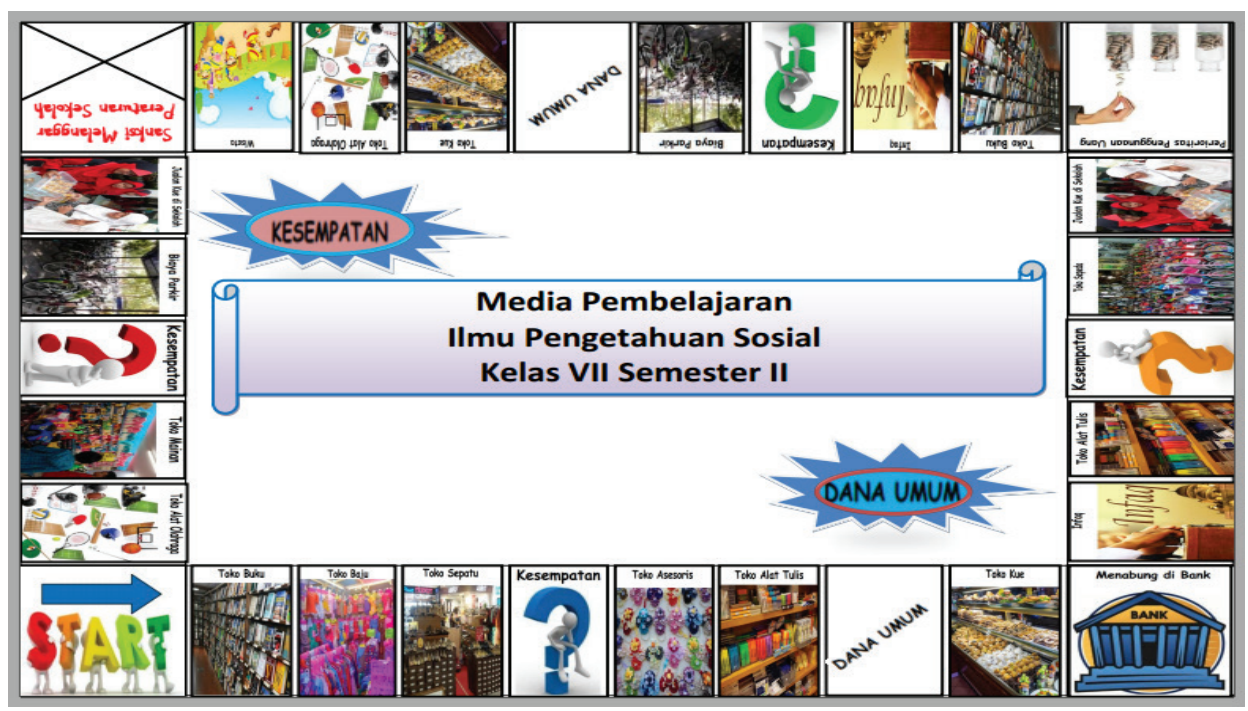

Picture 1. Monopoly Media In Stages, Feasibility test I 


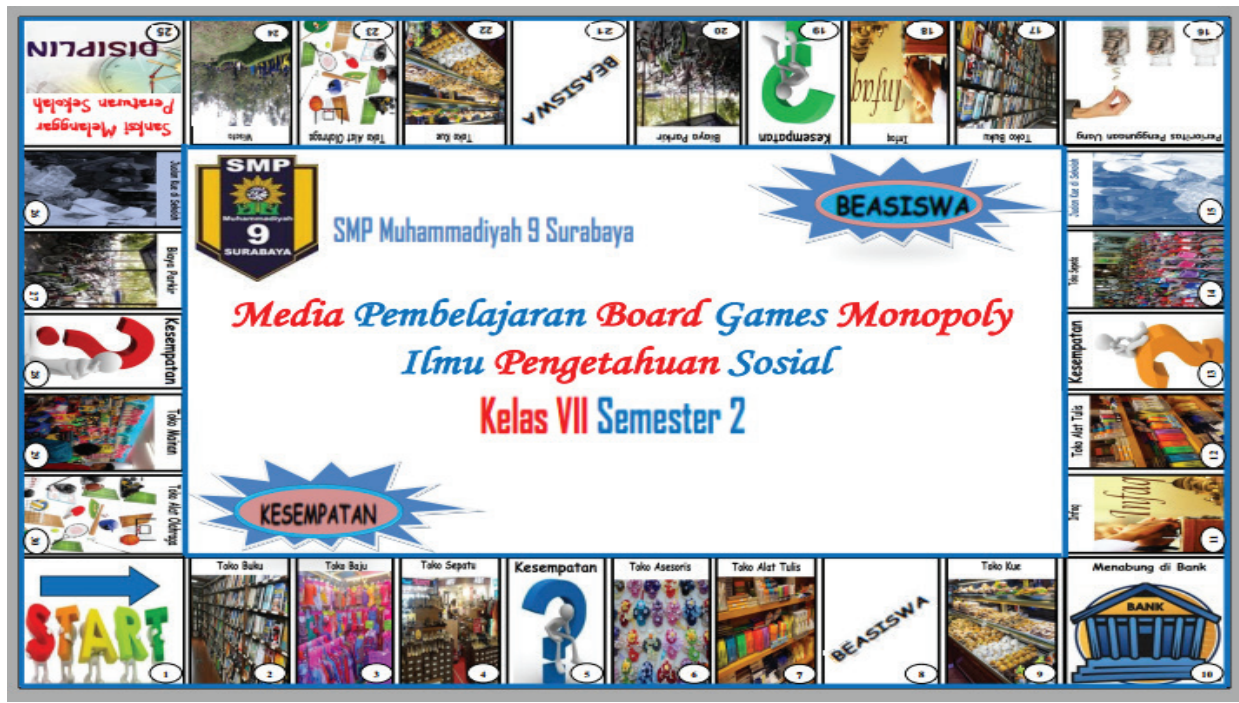

Picture 2. Monopoly Learning Media in Stages, Feasibility test II

Evaluation of the results of the first and second validation or feasibility tests results in different products, namely in terms of the material's design and content. Comparison of the results of validation on the developed media material reveals in the first product assessment of products $60 \%$ (not good), $70 \%$ (fair enough), and 80\% (right). So it still needs to be revised again. After revision and revalidation, the learning media products get $80 \%$ good and $90 \%$ excellent. In this case, the Social Sciences study's learning media deserves to be used for student learning.

Learning can be done anywhere, anytime, and in various forms, both psychomotor, affective, and cognitive. Based on the problems encountered by researchers in learning in class, students when they find the change in the third hour, and so on, students tend to decrease motivation to learn in social science subjects (IPS). Social studies understand the characteristics of many social science study materials (IPS) in explanations and the form of descriptive sentences. They are presented in the field of study, so students need to get a new learning media design to increase learning motivation and learning outcomes at the same time.

Evaluation of the results of the first and second validation or feasibility tests results in different products, namely in terms of the material's design and content. Comparison of the results of validation on the developed media material unveils in the first product assessment of products 60\% (not good), $70 \%$ (fair enough), and 80\% (right). So it still needs to be revised again. After revision and revalidation, learning media products get $80 \%$ good and $90 \%$ excellent, so in this case, the Monopoly learning media on Social Sciences studies deserves to be used for student learning. 
The Influence of the Use of Monopoly Learning Media on the Level of Student Motivation in Social Sciences (Social Sciences) Class VII

The Study of Social Sciences (IPS) is a study that studies human nature and social behavior. The main object of the social studies discussion is humans or society. As Winataputra explained, IPS have a vision of learning to shape students' character as social actors who can reason, be smart, be responsible, and be active (Iwan Setiawan, dkk.:2013).

The characteristics of learning material in the Social Sciences (IPS) field of study in the 2013 curriculum are dominant in inviting students to reason on social case studies. Social studies teaching materials also tend to be presented in the description of the material, so it takes a strong encouragement to understand the majority of the material in the form of descriptive sentences. Encouragement in these students can be referred to as a student's motivation learning.

Mc.Donald explained that motivation in a person has a sign of a feeling preceded by a response to the goals to be achieved. According to Mc. Donald, there are three essential elements in the characteristics of motivation in a person: the first motivation to initiate changes in someone's actions. Changes in these actions are shown by the existence of neurophysiological changes in a person. Second, motivation is characterized by feelings and affections in a person. It thus shows that motivation is closely related to the mental, emotional, and affective elements that have a strong influence on one's behavior. Third, motivation in a person because of the goals to be achieved by that person (Sardiman:2007).

Comparison before and after Monopoly learning media implemented in social science learning (IPS) in class VII is much different. Before the Monopoly learning media was implemented from observations made by researchers and social science teachers (IPS) in class VII B, students of class VII B had a tendency when attending social science learning (social studies) at the 3rd and 4th hours. They tended to be less motivated to learn. It is thus marked by students starting to not focus on paying attention to the teacher's explanation, talking alone with friends, and understanding the material becomes slow. Whereas when Monopoly learning media is implemented, students seem to be very enthusiastic about learning social science material (IPS), students have an extended focus power and understanding of material quickly.

Motivation in a person has two components: components from within a person (inner component) and components from outside oneself (outer component). Components from within a person are everything from within a person, be it a feeling of satisfaction or dissatisfaction with a matter that influences a person's desire to act. In comparison, outside oneself, components 
are all things that come from outside oneself that affect desire and behavior (Oemar Hamalik:1992).

Based on these explanations, students of class VII B, after completing social science learning (IPS) using Monopoly learning media, feel quite satisfied by spending two hours learning by using new learning media. Besides, students are eager to attend social science learning (IPS) in the upcoming meeting.

As Maslow explained that a person's needs had been met, it will influence meeting other needs at a higher level. There are five arrangements of the needs of every person who wants to be met, namely the first physiological needs, security, the desire to be loved, self-esteem, and the need to actualize themselves (Oemar Hamalik:1992).

Students actively play monopoly games on social studies learning opportunities using Monopoly learning media while understanding the material implicit in monopoly gameplay. Through monopoly games also eliminate students' fear in terms of the delivery of income in one group or with another group, because students are recorded in-game situations to feel more relaxed and comfortable. Students, when using Monopoly learning media, can actualize themselves in every turn of the game obtained, each student in the game gets the opportunity to play Monopoly learning media. Awards are also given to students who have succeeded in getting the highest score from the Monopoly monopoly of social science (IPS). The award can be in the form of applause from other friends, get an additional assignment from the teacher, and praise.

\section{Conclusion}

When Monopoly learning media is implemented, students look highly enthusiastic about learning social science material (IPS). Students have an extended focus on power and understanding of the material quickly. Students feel quite satisfied by spending two hours of learning by using new learning media. Through monopoly games also eliminate students' fear in terms of the delivery of income in one group or with another group, because students are recorded in-game situations to feel more relaxed and comfortable. Students can actualize themselves in every turn of the game that is obtained. Awards are also given to students who have succeeded in getting the highest score from the game.

\section{References}

Hamalik Oemar. 1992. Psikologi Belajar dan Mengajar. Bandung: Sinar Baru

A.M. Sardiman. 2007. Interaksi \& Motivasi Belajar Mengajar. Jakarta: PT. RajaGrafindo Persada

Setiawan Iwan, dkk. (Penelaah).2013. Buku Guru Ilmu Pengetahuan Sosial Kurikulum 2013 SMP/MTs Kelas VII. 2013. Jakarta: Kementerian Pendidikan dan Kebudayaan 
Sugiyono. 2013. Metode Penelitian Kuantitatif, Kualitatif dan R\&D. Bandung: Alfabeta Arikunto Suharsimi. Prosedur Penelitian Suatu Pengantar Praktik. 2006. Jakarta: PT.Rineka Cipta

Upe Ambo. 2010. Asas-Asas Multiple Research. Yogyakarta: Tiara Wacana
Sutarti Tatik dan Edi Irawan. 2017. Kiat Sukses Meraih Hibah Penelitian Pengembangan. Sleman: CV.Budi Utama

Huda Miftahul. 2014. Model-modelPengajaran dan Pembelajaran. Yogyakarta: Pustaka Pelajar 